\title{
Salt Solubility Products of Diprenorphine Hydrochloride, Codeine and Lidocaine Hydrochlorides and Phosphates - Novel Method of Data Analysis Not Dependent on Explicit Solubility Equations
}

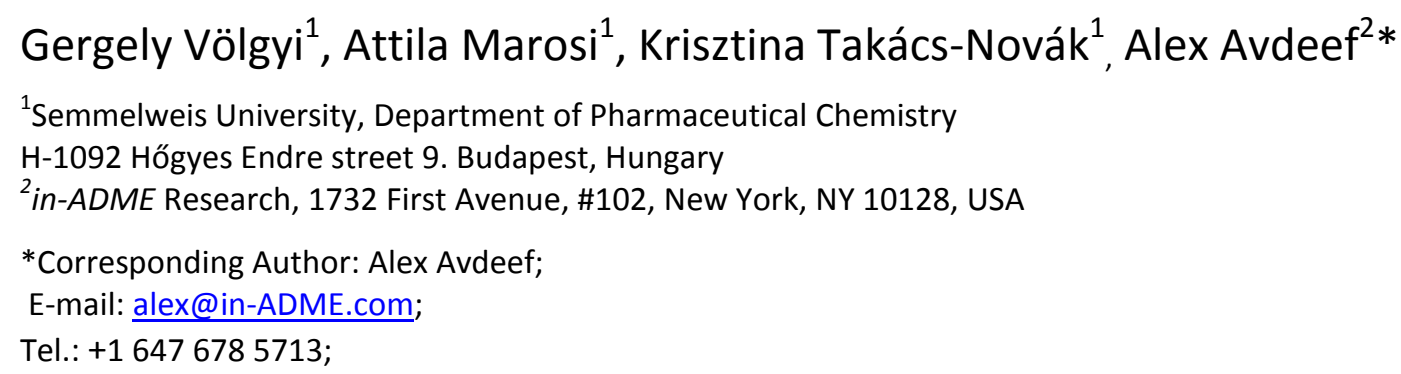

\begin{abstract}
A novel general approach was described to address many of the challenges of salt solubility determination of drug substances, with data processing and refinement of equilibrium constants encoded in the computer program pDISOL$X^{T M}$. The new approach was illustrated by the determinations of the solubility products of diprenorphine hydrochloride, codeine hydrochloride and phosphate, lidocaine hydrochloride and phosphate at $25{ }^{\circ} \mathrm{C}$, using a recently-optimized saturation shake-flask protocol. The effects of different buffers (Britton-Robinson universal and Sörensen phosphate) were compared. Lidocaine precipitates were characterized by X-ray powder diffraction (XRPD) and polarization light microscopy. The ionic strength in the studied systems ranged from 0.25 to $4.3 \mathrm{M}$. Codeine (and possibly diprenorphine) chloride were less soluble than the phosphates for $\mathrm{pH}>2$. The reverse trend was evident with lidocaine. Diprenorphine saturated solutions showed departure from the predictions of the Henderson-Hasselbalch equation in alkaline ( $\mathrm{pH}>9$ ) solutions, consistent with the formation of a mixed-charge anionic dimer.
\end{abstract}

\section{Keywords}

sparingly-soluble drugs; pH-dependent solubility; salt solubility products, solubility equations; aggregation; shake-flask method.

\section{Introduction}

Salt selection in preformulation is an important step in the preparation of effective oral drug formulations [1-8]. Salt solubility, being a conditional constant, takes on different values according to the concentrations and types of reactants used in a particular study. For this reason, laboratory-to-laboratory comparisons can be complicated, possibly leading to conflicting interpretations of in vitro dissolution studies in formulation development. On the other hand, salt solubility products are true equilibrium constants. But these are not often reported in published salt solubility studies. Interpretation and scaling of salt solubility measurements can be very challenging for a number of reasons. 
- Since drug salts are often much more soluble than the corresponding uncharged forms, salt solubility measurement is usually carried out in relatively concentrated solutions, with ionic strengths, I, often exceeding $1 \mathrm{M}$.

- At these high levels, activity coefficients of ions are poorly controlled and cannot be accurately predicted by the traditional Debye-Hückel equation.

- Also, pH electrodes calibrated in buffers with I = $0.15 \mathrm{M}$ ("physiological" level) may not be accurate at much higher ionic strengths, especially in the extreme regions of $\mathrm{pH}(<1$ or $>12)$ where electrode junction potentials may be very different from those characteristic of the physiological level.

- The salt solubility is a conditional constant, which depends not only on the concentration of the drug but also on that of the counterion with which the charged drug precipitates. The counterion may originate from the buffer used or other unsuspecting solution additives.

- Under such high sample concentrations, many drugs, especially those likely to be surface-active, can form micelles, self-associated aggregates (dimers, trimers, or higher-order oligomers), or complexes with buffer species or other solution additives.

All these effects can complicate the interpretation of the solubility data [9-18]. Such complexity may not be evident unless a full solubility - $\mathrm{pH}$ profile is measured, over a $\mathrm{pH}$ range containing the uncharged and charged forms of the drug, preferably at more than one solid-sample excess. Carefully planned experimental designs and complicated computations are often needed to correctly interpret the measured salt solubility.

Although explicit solubility equations (cf., Appendix A) have been derived for many different cases of salt solubility and aggregation [19], it is hardly practical to derive such equations for the vast number of possible forms of salt and aggregation stoichiometry that can be encountered. For this reason, salt solubility analysis of data in the past had been done on a case by case basis, sometimes using incomplete explicit solubility equations. At times the impact of aggregation reactions had been recognized but not dealt with quantitatively, presumably because computational methods were not available at the time $[9,10,16]$.

In this study we describe a novel general approach to address many of the challenges of salt solubility determination, with data processing and refinement of equilibrium constants encoded in the computer program pDISOL- $X^{\mathrm{TM}}$ (in-ADME Research). The new approach was illustrated by the determinations of the solubility products of three model drugs: diprenorphine hydrochloride, codeine hydrochloride and phosphate, lidocaine hydrochloride and phosphate. Diprenorphine, whose solubility-pH profile had not been reported, is primarily used as an opioid antagonist to reverse the effects of etorphine and carfentanyl. Codeine is a naturally-occurring analgesic opiate. Lidocaine is a local anesthetic. The effects of different buffers (Britton-Robinson universal and Sörensen phosphate) were compared. Lidocaine precipitates were characterized by X-ray powder diffraction and polarization light microscopy. The ionic strength in the studied systems ranged from 0.25 to $4.3 \mathrm{M}$.

\section{Experimental}

\section{Chemicals}

Codeine hydrochloride, codeine phosphate, lidocaine free base and lidocaine hydrochloride were purchased from Sigma and used without further purification. Diprenorphine hydrochloride was an in-house synthesized compound and was of analytical grade. 
Potassium hydroxide and hydrochloric acid used for $\mathrm{p} K_{\mathrm{a}}$ determination were from Sigma. The $\mathrm{KOH}$ titrant solution was standardized by titration against primary standards potassium hydrogen phthalate dissolved in $15 \mathrm{~mL}$ of $0.15 \mathrm{M}$ potassium chloride. Potassium hydrogen phthalate and potassium chloride were of analytical grade and were purchased from Sigma. The $\mathrm{HCl}$ titrant solution was standardized by titrating a measured volume against the standardized $\mathrm{KOH}$.

Two buffer solutions (Britton-Robinson universal and Sörensen phosphate) were used at pH 5 in the shake-flask experiments of codeine and lidocaine. Britton-Robinson buffer solution (mixture of acetic, phosphoric and boric acids, each at $0.04 \mathrm{M}$ ) was treated with $0.2 \mathrm{M} \mathrm{NaOH}$ to give the required $\mathrm{pH}$. The Sörensen phosphate buffer solutions were prepared by mixing $0.067 \mathrm{M} \mathrm{Na}_{2} \mathrm{HPO}_{4}$ and $0.067 \mathrm{M} \mathrm{KH}_{2} \mathrm{PO}_{4}$ solutions to reach the required $\mathrm{pH}(4.8-8.5)$. Phosphate-containing solutions between $\mathrm{pH} 1$ and 12.5 were used for the equilibrium solubility measurements of diprenorphine, where $0.5 \mathrm{M} \mathrm{KOH}, 0.5 \mathrm{M}$ or $14.85 \mathrm{M}$ $\mathrm{H}_{3} \mathrm{PO}_{4}$ (standardized 85\%) solutions were used to reach the desired $\mathrm{pH}$ values. Distilled water of Ph. Eur. grade was used. All other reagents were of analytical grade.

\section{pH Electrode Standardization and Compensation for Large Changes in lonic Strength}

All of the equilibrium constants reported here are based on the concentration scale, i.e., the "constant ionic medium" thermodynamic standard state [19]. Since the measured $\mathrm{pH}$ is based on the operational activity scale, these values need to be converted to the concentration scale, $p_{c} H\left(=-\log \left[H^{+}\right]\right)$. The procedure to calibrate and standardize the $\mathrm{pH}$ electrode is described in detail elsewhere [19]. Briefly, the electrode is standardized by the blank titration method: to a $0.15 \mathrm{M} \mathrm{KCl}$ solution, enough standardized $0.5 \mathrm{M} \mathrm{HCl}$ is added to lower the $\mathrm{pH}$ to $1.8(0.87 \pm 0.03 \mathrm{~mL}$ when using a $20 \mathrm{~mL}$ solution); then the acidified solution is precisely titrated with standardized $0.5 \mathrm{M} \mathrm{KOH}$ up to about $\mathrm{pH} 12.2$ (which consumes about $2 \mathrm{~mL} 0.5 \mathrm{M}$ $\mathrm{KOH})$. The blank titration $\mathrm{pH}$ data are fit to a four-parameter equation [20]:

$$
\mathrm{pH}=\alpha+\mathrm{k}_{\mathrm{S}} \mathrm{p}_{\mathrm{c}} \mathrm{H}+\mathrm{j}_{\mathrm{H}}\left[\mathrm{H}^{+}\right]+\mathrm{j}_{\mathrm{OH}} K_{\mathrm{w}} /\left[\mathrm{H}^{+}\right]
$$

where $K_{\mathrm{w}}$ is the ionization constant of water. The $\mathrm{j}_{\mathrm{H}}$ term corrects $\mathrm{pH}$ readings for the nonlinear $\mathrm{pH}$ response due to liquid junction and asymmetry potentials in highly acidic solutions $(\mathrm{pH}<2)$, while the $\mathrm{j}_{\mathrm{OH}}$ term corrects for high-pH nonlinear effects [19]. Typical values of the adjustable parameters at $25^{\circ} \mathrm{C}$ and $0.15 \mathrm{M}$ ionic strength are $\alpha=0.09, \mathrm{k}_{\mathrm{S}}=1.002, \mathrm{j}_{\mathrm{H}}=0.5$ and $\mathrm{j}_{\mathrm{OH}}=-0.5$. However, each electrode indicates its own characteristic set.

Since salt solubility measurements can be under conditions where ionic strength may reach values as high as $1 \mathrm{M}$, the experimentally-determined parameters in Eq. (1), based on the "reference" ionic strength $0.15 \mathrm{M}$, are automatically compensated by the computational procedure in $\mathrm{pDISOL-X}$, for changes in ionic strength from the reference value $0.15 \mathrm{M}$ to the actual values in a particular solubility assay, according to the empirically-determined relationships defined elsewhere [19].

\section{$p K_{a}$ Determination}

The $\mathrm{p} K_{\mathrm{a}}$ values of diprenorphine were determined by potentiometry using a GLpKa instrument (Sirius, Forest Row, UK) equipped with a combination $\mathrm{Ag} / \mathrm{AgCl} \mathrm{pH}$ electrode. The titrations were carried out at constant ionic strength $(I=0.15 \mathrm{M} \mathrm{KCl})$ and temperature $\left(T=25.0 \pm 0.5{ }^{\circ} \mathrm{C}\right)$, and under nitrogen atmosphere. Aqueous solutions of diprenorphine hydrochloride $(10 \mathrm{~mL}, 0.7-0.8 \mathrm{mM})$ were pre-acidified to 
$\mathrm{pH} 2$ with $0.5 \mathrm{M} \mathrm{HCl}$, and then titrated with $0.5 \mathrm{M} \mathrm{KOH}$ to $\mathrm{pH}$ 12. Three parallel measurements were carried out. The $\mathrm{p} K_{\mathrm{a}}$ values were calculated by the RefinementPro ${ }^{\mathrm{TM}}$ software (Sirius, Forest Row, UK).

\section{Solubility Measurements by Saturation Shake-flask Method}

In the shake-flask experiments, the pH of the solutions was measured by a Radiometer PHM $220 \mathrm{pH}$ meter with combined $\mathrm{Ag} / \mathrm{AgCl}$ glass electrode. The temperature of the samples was maintained at $25.0 \pm$ $0.5^{\circ} \mathrm{C}$ during the solubility measurements using a Lauda thermostat. A Heidolph MR 1000 magnetic stirrer was used to mix the two phases. The concentration in the supernatant was measured by spectroscopy using a Jasco V-550 UV/VIS spectrophotometer.

To facilitate the measure of concentration by UV spectrophotometry, the specific absorbance $\left(\mathrm{A}_{1 \mathrm{~cm}}{ }^{1 \%}\right.$, the absorbance of $1 \mathrm{~g} / 100 \mathrm{~mL}$ solution over a $1 \mathrm{~cm}$ optical path length at a given wavelength) of each sample at the given $\mathrm{pH}$ values was determined separately at a selected wavelength using $12-18$ points of a minimum of two parallel dilution series, from the linear regression equation (Lambert-Beer law).

The equilibrium solubility of the samples at different $\mathrm{pH}$ values was determined by the new protocol of saturation shake-flask method [21]. The sample was added to the aqueous Britton-Robinson universal and Sörensen phosphate buffers (codeine and lidocaine) or phosphate-containing solution (diprenorphine) until a heterogeneous system (solid sample and liquid) was obtained. The solution containing solid excess of the sample was stirred for a period of 6 hours (saturation time) at controlled temperature allowing it to achieve thermodynamic equilibrium. After a further 18 hours of sedimentation, the concentration of the saturated solution was measured by UV spectroscopy. Three aliquots were taken out with a fine pipette (5$500 \mu \mathrm{L}$ ) from the liquid and diluted with the solvent if necessary. At least three parallel concentration measurements were carried out and the result was calculated using 9-12 data points. The standard deviation varied from $1-13 \%$.

\section{Refinement of Intrinsic and Salt Solubility and Aggregation Constants}

The new data analysis method uses logS - $\mathrm{pH}$ as measured input data (along with the standard deviations in $\log S$ ) into the computer program. The data can be UV-derived, potentiometric-derived, etc. An algorithm was developed which considers the contributions of all species present in solution, including universal buffer components (e.g., Britton-Robinson, Sörensen, Prideaux-Ward, etc.). The approach does not depend on any explicitly derived extensions of the Henderson-Hasselbalch equations. The computational algorithm derives its own implicit equations internally, given any practical number of equilibria and estimated constants, which are subsequently refined by weighted nonlinear leastsquares regression. So, in principal, drug-salt precipitates, -aggregates, -complexes, - bile salts, -surfactant can be accommodated [19]. Specific buffer-drug formed species can be tested, as is often necessary with phosphate-, and sometimes, citrate-containing buffers. The program assumes an initial condition of a suspension of the solid drug in a solution often containing a background electrolyte, e.g., $0.15 \mathrm{M} \mathrm{NaCl}$, ideally with the suspension saturated over a wide range of $\mathrm{pH}$. The computer program calculates the distribution of species corresponding to a sequence of additions of standardized strong-acid titrant $\mathrm{HCl}$ (or weak-acid titrants $\mathrm{H}_{3} \mathrm{PO}_{4}, \mathrm{H}_{2} \mathrm{SO}_{4}$, acetic acid, maleic acid, lactic acid) to simulate the suspension speciation down to $\mathrm{pH} \sim 0$, the staging point for the next operation. A sequence of perturbations with standardized $\mathrm{NaOH}$ (or $\mathrm{KOH}$ ) is simulated, and solubility calculated at each point (in pH steps of 0.005-0.2), until pH 13 is reached. The ionic strength is rigorously calculated at each step (cf, Appendix B), and $\mathrm{p} K_{\mathrm{a}}$ values (as well as solubility products, aggregation and complexation constants) are accordingly adjusted (cf., Appendix 
B). Nonlinear pH electrode standardization parameters (Eq. 1) are included in the calculation [20], a feature that is especially important for measurement of accurate $\mathrm{pH}$ in the extreme $\mathrm{pH}(<1$ or $>12)$ regions.

At the end of the speciation simulation, the calculated logS vs. $\mathrm{pH}$ curve is compared to actual measured $\log S$ vs. $\mathrm{pH}$. A logS-weighted nonlinear least squares refinement commences to refine the proposed equilibrium model, using analytical expressions for the differential equations.

The process is repeated until the differences between calculated and measured logs values reach a minimum. Specifically, the $\log S-\mathrm{pH}$ data are refined to minimize the weighted residual function,

$$
R_{w}=\sum_{i}^{N} \frac{\left(\log S_{i}^{\text {obs }}-\log S_{i}^{\text {calc }}\right)^{2}}{\sigma_{i}^{2}(\log S)}
$$

where $N$ is the measured number of solubility values used to test the model, and $\log S_{i}^{\text {calc }}$ is the calculated log solubility values. The estimated standard deviation in the observed $\log S, \sigma_{\mathrm{i}}$, is estimated as 0.10 (log units), or is set equal to the values reported in the measurement. The overall quality of the refinement is assessed by the "goodness-of-fit" (GOF),

$$
G O F=\sqrt{\frac{R_{w}}{N-N_{p}}}
$$

where $N_{\mathrm{p}}$ is the number of refined parameters. If a proposed model fits the data well, and accurate weighting factors are used, then GOF = 1 is the statistically expected value.

\section{Results and Discussion}

Table 1 summarizes some of the physicochemical properties of the three model compounds, including the $\mathrm{p} K_{\mathrm{a}}$ constants of diprenorphine determined in this work. Table 2 lists the shake-flask solubility measurement details, including the actual weights of compounds added to form the saturated solutions. In critical salt solubility studies, it is often necessary to state the actual weight of compound added, and not just state that "excess solid was added." This is because salt solubility constants are conditional, and in some cases require the actual weights to determine solubility products, especially when aggregates form in saturated solutions or when salt stoichiometries are complex. In Table 2, the calculated volumes of 14.85 $\mathrm{M} \mathrm{H}_{3} \mathrm{PO}_{4}$ or $0.5 \mathrm{M} \mathrm{KOH}$ titrants used to adjust the $\mathrm{pH}$ are normalized to $1 \mathrm{~mL}$ total solution volumes (actual volumes ranged from 0.5 to $15 \mathrm{~mL}$ ). Table 3 lists the equilibrium constants determined and critical concentrations (including ionic strength and buffer capacity) calculated in the various assays.

The $\mathrm{p} K_{\mathrm{a}}$ values of the model compounds are listed in Table 1 at standard state conditions $\left(I_{\text {ref }}=0.15 \mathrm{M}\right.$, $25{ }^{\circ} \mathrm{C}$ ), but the primed constants in Table 3 are those that were actually applied at the specific ionic strength $(0.25-4.34 \mathrm{M})$, calculated as described in Appendix B. Those of diprenorphine changed slightly by 0.0 to $+0.05\left(\mathrm{p} K_{\mathrm{a} 1}\right)$ and 0.0 to $-0.04\left(\mathrm{p} K_{\mathrm{a} 2}\right)$; that of codeine +0.02 to +0.14 ; that of lidocaine +0.15 to +0.51. According to the simple Debye-Hückel theory, those of monoprotic bases are expected not to change, but Eq. B5 predicts otherwise. Also listed in Table 3 are the actual $p K_{\text {sp }}$ values used at the particular ionic strengths, compared to those at $I_{\text {ref. }}$. 
Table 1. Physicochemical properties, $25^{\circ} \mathrm{C}$.

\begin{tabular}{|lcccc|}
\hline Compound & MW & $\log \boldsymbol{P}$ & $\mathbf{p} \boldsymbol{K}_{\mathrm{a}}$ & $\begin{array}{c}\text { Literature } \\
-\log \boldsymbol{S}_{0}=\mathbf{p} S_{0}[\mathrm{M}]\end{array}$ \\
\hline Diprenorphine & 425.56 & $3.81^{\mathrm{a}}$ & $9.68 \pm 0.01^{\mathrm{d}}, 8.52 \pm 0.01^{\mathrm{d}}$ & -- \\
\hline Codeine & 299.36 & $1.19^{\mathrm{b}}$ & $8.24^{\mathrm{b}}$ & $1.52^{\mathrm{e}}$ \\
\hline Lidocaine & 234.34 & $2.44^{\mathrm{c}}$ & $7.95^{\mathrm{c}}$ & $2.04^{\mathrm{f}}, 1.88^{\mathrm{g}}, 1.75^{\mathrm{h}}, 1.71^{\mathrm{i}}$ \\
\hline
\end{tabular}

${ }^{a}$ Calculated using ADME Boxes 4.9 (ACD Labs, Toronto). ${ }^{\mathrm{b}}\left[22{ }^{\mathrm{c}}\left[23{ }^{\mathrm{d}}\right.\right.$ This work.

${ }^{\mathrm{e}}[24]^{\mathrm{f}}[16] \cdot{ }^{\mathrm{g}}[25]^{\mathrm{h}}[26]^{\mathrm{i}}[27]$

The solubility products are also affected significantly when $I \gg I_{\text {ref }}$. For example, the phosphate $\mathrm{p} K_{\mathrm{sp}}$ of codeine phosphate decreased from $1.00\{1.11\}$ at $I_{\text {ref }}$ to $-0.07\{0.02\}$ at $I=1.21\{1.07\} \mathrm{M}$, where the braced value refers to Britton-Robinson universal and the unbraced value refers to Sörensen buffer measurements (Table 3). Lidocaine showed similar large shifts due to the large $I=4.34\{3.81\} \mathrm{M}$. The changes were much smaller for the codeine chloride $\mathrm{p} K_{\mathrm{sp}}$, since $I=0.33\{0.24\} \mathrm{M}$.

Table 2. Shake-flask solubility data, $25^{\circ} \mathrm{C}^{a}$

\begin{tabular}{|c|c|c|c|c|c|c|}
\hline pH & Buffer & $\begin{array}{c}\mathrm{V}(14.85 \\
\left.\mathrm{M} \mathrm{H}_{3} \mathrm{PO}_{4}\right) \\
/ \mathrm{ml}^{\mathrm{b}}\end{array}$ & $\begin{array}{c}\mathrm{V}(0.5 \mathrm{M} \mathrm{кOH}) \\
/ / \mathrm{ml}^{\mathrm{b}}\end{array}$ & $S\left(\mathrm{mg} \mathrm{mL}^{-1}\right)$ & $\begin{array}{l}\text { Sample Wt. } \\
\qquad\left(\mathrm{g} \mathrm{mL}^{-1}\right)\end{array}$ & $\begin{array}{c}\text { Expected } \\
\text { Precipitate }\end{array}$ \\
\hline 0.83 & Sör & 0.4998 & 0.0000 & $4.98 \pm 0.04$ & 0.0307 & $\mathrm{XH}_{2}{ }^{+} \mathrm{H}_{2} \mathrm{PO}_{4}^{-}(\mathrm{s})$ \\
\hline 1.94 & Sör & 0.0111 & 0.0000 & $54.1 \pm 1.1$ & 0.0601 & $\mathrm{XH}_{2}^{+} \mathrm{Cl}^{-}(\mathrm{s})$ \\
\hline 3.53 & Sör & 0.0003 & 0.0000 & $45.2 \pm 0.9$ & 0.0634 & $\begin{array}{c}\mathrm{XH}_{2}{ }^{+} \mathrm{Cl}^{-}(\mathrm{s}) \\
\mathrm{XH}_{2}{ }^{+} \mathrm{Cl}^{-}(\mathrm{s})+\end{array}$ \\
\hline 5.06 & Sör & 0.0000 & 0.0082 & $45.1 \pm 1.2$ & 0.0637 & $X H(s)$ \\
\hline 7.22 & Sör & 0.0000 & 0.4969 & $0.249 \pm 0.014$ & 0.0050 & $\mathrm{XH}(\mathrm{s})$ \\
\hline 8.34 & Sör & 0.0000 & 0.5702 & $0.088 \pm 0.021$ & 0.0114 & $\mathrm{XH}(\mathrm{s})$ \\
\hline 8.83 & Sör & 0.0000 & 0.5759 & $0.032 \pm 0.001$ & 0.0007 & $\mathrm{XH}(\mathrm{s})$ \\
\hline 10.38 & Sör & 0.0000 & 0.6251 & $0.667 \pm 0.008$ & 0.0106 & $\mathrm{XH}(\mathrm{s})$ \\
\hline 11.52 & Sör & 0.0000 & 0.8274 & $4.79 \pm 0.11$ & 0.0051 & $\mathrm{XH}(\mathrm{s})$ \\
\hline 5.00 & $\mathrm{BR}$ & 0.0000 & 0.1376 & $52.0 \pm 0.1$ & 0.1050 & $\mathrm{BH}^{+} \mathrm{Cl}^{-}(\mathrm{s})$ \\
\hline 5.00 & Sör & 0.0000 & 0.0044 & $53.0 \pm 0.1$ & 0.1535 & $\mathrm{BH}^{+} \mathrm{Cl}^{-}(\mathrm{s})$ \\
\hline 5.00 & BR & 0.0000 & 0.1716 & $290 \pm 38$ & 0.4950 & $\mathrm{BH}^{+} \mathrm{H}_{2} \mathrm{PO}_{4}^{-}(\mathrm{s})$ \\
\hline 5.00 & Sör & 0.0000 & 0.0390 & $308 \pm 30$ & 0.5305 & $\mathrm{BH}^{+} \mathrm{H}_{2} \mathrm{PO}_{4}^{-}(\mathrm{s})$ \\
\hline 5.00 & $B R$ & 0.2149 & 0.0000 & $310 \pm 15$ & 0.7700 & $\mathrm{BH}^{+} \mathrm{H}_{2} \mathrm{PO}_{4}^{-}(\mathrm{s})$ \\
\hline 5.00 & Sör & 0.2940 & 0.0000 & $294 \pm 10$ & 1.0300 & $\mathrm{BH}^{+} \mathrm{H}_{2} \mathrm{PO}_{4}^{-}(\mathrm{s})$ \\
\hline 5.00 & $\mathrm{BR}$ & 0.0000 & 0.0064 & $>1000$ & 1.0300 & $\mathrm{BH}^{+} \mathrm{Cl}^{-}(\mathrm{s})$ \\
\hline 5.00 & Sör & 0.0000 & 0.0042 & $>1000$ & 1.1354 & $\mathrm{BH}^{+} \mathrm{Cl}^{-}(\mathrm{s})$ \\
\hline
\end{tabular}

${ }^{\mathrm{a}}$ Sör = Sörensen buffer $(0.15 \mathrm{M}$ phosphate, adjusted with $\mathrm{NaOH}) . \quad \mathrm{BR}=$ Britton-Robinson universal buffer (acetic, phosphoric, and boric acids, each at $0.04 \mathrm{M}$, adjusted with $\mathrm{NaOH}$ to $\mathrm{pH} 5$ ). ${ }^{\mathrm{b}}$ Calculated by $\mathrm{pDISOL}-\mathrm{X}$.

The $\mathrm{p} K_{\mathrm{a}}$ values of the acetate, phosphate, and borate buffer components used were taken from Wiki-pK ${ }_{a}$ website (<http://www.in-ADME.com/wiki_pka.php/>). These were automatically adjusted for changes in the ionic strength by $p D I S O L-X$. The changes were most pronounced with phosphoric acid $(0.17$ $-0.62)$, and were minimal with acetic and boric acids (0.01-0.06). 
Table 3 - Equilibrium Constants $\left(24 \mathrm{~h} \text { incubation, } 25^{\circ} \mathrm{C}\right)^{\mathrm{a}}$

\begin{tabular}{|c|c|c|c|c|c|c|c|c|c|c|c|c|c|c|}
\hline $\mathrm{pH}$ & & $\begin{array}{c}\text { Buffer } \\
\text { Capacity } \\
(\mathrm{mM} / \mathrm{pH})\end{array}$ & $\begin{array}{l}\text { Ionic } \\
\text { Str. } \\
\text { (M) }\end{array}$ & $\begin{array}{c}\mathbf{p K}_{\mathrm{a}}{ }^{\prime} \\
\text { (base) }\end{array}$ & $\begin{array}{l}\mathbf{p K}_{\mathbf{a}}{ }^{\prime} \\
\text { (acid) }\end{array}$ & $\begin{array}{l}\text { pK }_{\mathrm{Bp}} \mathrm{p}^{\prime} \\
\text { (phos- } \\
\text { phate) }\end{array}$ & $\begin{array}{c}\mathbf{p K}_{\mathrm{Bp}}{ }^{\prime} \\
\text { (chloride) }\end{array}$ & $\begin{array}{c}{\left[\mathrm{BH}^{+}\right] \text {or }} \\
{\left[\mathrm{XH}_{2}^{+}\right]}\end{array}$ & {$\left[\mathrm{Cl}^{-}\right]$} & {$\left[\mathrm{H}_{2} \mathrm{PO}_{4}^{-}\right]$} & $\begin{array}{c}{[\mathrm{BH}][\mathrm{Cl}]} \\
\text { or } \\
{\left[\mathrm{XH}_{2}\right][\mathrm{Cl}]}\end{array}$ & $\begin{array}{c}{[\mathrm{BH}]\left[\mathrm{H}_{2} \mathrm{PO}_{4}\right]} \\
\text { or } \\
{\left[\mathrm{XH}_{2}\right]\left[\mathrm{H}_{2} \mathrm{PO}_{4}\right]}\end{array}$ & $\mathrm{pK}_{\mathrm{Bp}}$ & $\mathrm{pS}_{0}$ \\
\hline \multicolumn{15}{|c|}{ Diprenorphine Hydrochloride } \\
\hline 0.83 & Sör & 1183 & 0.40 & 8.55 & 9.65 & & 1.96 & 0.088 & 0.088 & 0.314 & 0.008 & 0.028 & $\begin{array}{c}2.06 \pm \\
0.07\end{array}$ & $\begin{array}{c}4.60 \pm \\
0.08\end{array}$ \\
\hline 1.94 & Sör & 242 & 0.26 & 8.54 & 9.66 & & 2.01 & 0.099 & 0.099 & 0.163 & 0.010 & 0.016 & & \\
\hline 3.53 & Sör & 12 & 0.25 & 8.53 & 9.67 & & 2.02 & 0.098 & 0.098 & 0.150 & 0.010 & 0.015 & & \\
\hline 5.06 & Sör & 8 & 0.25 & 8.53 & 9.66 & & 2.01 & 0.098 & 0.099 & 0.146 & 0.010 & 0.014 & & \\
\hline 7.22 & Sör & 169 & 0.34 & 8.55 & 9.65 & & 1.98 & 0.001 & 0.093 & 0.026 & 0.000 & 0.000 & & \\
\hline 8.34 & Sör & 122 & 0.37 & 8.52 & 9.68 & & 1.97 & 0.000 & 0.088 & 0.002 & 0.000 & 0.000 & & \\
\hline 8.83 & Sör & 118 & 0.37 & 8.55 & 9.65 & & 1.97 & 0.000 & 0.088 & 0.001 & 0.000 & 0.000 & & \\
\hline 10.38 & Sör & 87 & 0.40 & 8.55 & 9.65 & & 1.96 & 0.000 & 0.086 & 0.000 & 0.000 & 0.000 & & \\
\hline 11.52 & Sör & 46 & 0.51 & 8.57 & 9.64 & & 1.93 & 0.000 & 0.076 & 0.000 & 0.000 & 0.000 & & \\
\hline \multicolumn{15}{|c|}{ Codeine Hydrochloride } \\
\hline 5.00 & $\mathrm{BR}$ & 20 & 0.24 & 8.26 & & $\mathrm{~b}$ & 1.52 & 0.173 & 0.173 & 0.037 & 0.030 & 0.006 & 1.57 & 1.52 \\
\hline 5.00 & Sör & 6 & 0.33 & 8.27 & & $\mathrm{~b}$ & 1.51 & 0.177 & 0.177 & 0.147 & 0.031 & 0.026 & 1.59 & 1.52 \\
\hline \multicolumn{15}{|c|}{ Codeine Phosphate } \\
\hline 5.00 & $\mathrm{BR}$ & 69 & 1.07 & 8.38 & & 0.02 & c & 0.967 & 0.000 & 0.984 & 0.000 & 0.952 & 1.11 & 1.52 \\
\hline 5.00 & Sör & 52 & 1.21 & 8.38 & & -0.07 & c & 1.026 & 0.000 & 1.152 & 0.000 & 1.182 & 1.00 & 1.52 \\
\hline \multicolumn{15}{|c|}{ Lidocaine (free base) } \\
\hline 5.00 & $\mathrm{BR}$ & 102 & 1.34 & 8.13 & & -0.22 & c & 1.319 & 0.000 & 1.248 & 0.000 & 1.647 & 0.88 & 2.04 \\
\hline 5.00 & Sör & 87 & 1.39 & 8.10 & & -0.22 & $\mathrm{c}$ & 1.250 & 0.000 & 1.318 & 0.000 & 1.647 & 0.85 & 2.04 \\
\hline \multicolumn{15}{|c|}{ Lidocaine Hydrochloride } \\
\hline 5.00 & $\mathrm{BR}$ & 63 & 3.81 & 8.43 & & $b$ & -1.16 & 3.789 & 3.789 & 0.021 & 14.357 & 0.078 & $-0.85^{d}$ & 2.04 \\
\hline 5.00 & Sör & 6 & 4.34 & 8.46 & & $b$ & -1.24 & 4.184 & 4.184 & 0.148 & 17.504 & 0.618 & $-0.99 d$ & 2.04 \\
\hline
\end{tabular}

- Concentrations are in molar units. Sör $=$ Sörensen buffer. BR = Britton-Robinson universal buffer, $X=$ ampholyte anion, $B=$ free base. Primed constants refer to the actual ionic strength

and are those used in the calculations. Non-primed constants are normalized to values at he $=0.15 \mathrm{M}$. "Solubility product not exceeded. "Chloride salt not possible since assay is chloride-free.

and are those used in the calculations. Non-primed consta
$d$ Based on minimum possible lidocaine chloride solubility.

\section{Diprenorphine Hydrochloride}

Figure 1a shows the logS vs. $\mathrm{pH}$ profile of diprenorphine hydrochloride $\left(\mathrm{XH}_{2}{ }^{+} \mathrm{Cl}^{-}\right)$. The dashed line is calculated with the Henderson-Hasselbalch equation (Eq. A5), using the two $p K_{\mathrm{a}}$ of diprenorphine. The solid curve was calculated based on the equilibrium model most consistent with the actual log $S$ measurements at the various $\mathrm{pH}$. For $\mathrm{pH}>\mathrm{pK}_{\mathrm{a}}^{\mathrm{GIBBS}}$ (5.07; cf., Appendix A), the precipitate is the uncharged ordinary ampholyte, showing the characteristic parabolic shape. The intrinsic solubility (molar units) was refined as $\mathrm{pS}_{0}=4.60 \pm 0.08\left(S_{0}=11.5 \pm 0.4 \mu \mathrm{g} \mathrm{mL}^{-1}\right)$.

At $\mathrm{pH}$ below the Gibbs $\mathrm{p} K_{\mathrm{a}}$, either the chloride or the phosphate salt precipitates (or possibly both). It is not easy to be certain which form precipitates unless several measurements are made at $\mathrm{pH}<2$, in order to exploit the common ion effect which would be evident for phosphate salt, since phosphoric acid was used to lower the $\mathrm{pH}$. The solubility at $\mathrm{pH} 0.83$ suggests that a phosphate precipitate may form at the very low $\mathrm{pH}$. In contrast, the chloride model predicts that all solid dissolves at $\mathrm{pH} 0.83$ (given the amount of sample added). The flat shape of the curve $\mathrm{pH} 2-5$ is most consistent with chloride precipitate. A phosphate precipitate would be expected to show an upward curvature near the Gibbs $\mathrm{p} K_{\mathrm{a}}$. The constant based on the assumed chloride precipitate is $p K_{\mathrm{sp}}=2.06 \pm 0.07\left(S_{\mathrm{XH}}=44.6 \pm 1.5 \mathrm{mg} \mathrm{mL}^{-1}\right.$, in hydrochloride equivalents).

At $\mathrm{pH}>9$, the logS $-\mathrm{pH}$ curve shows a shift to lower $\mathrm{pH}$, compared that what would be predicted from the Henderson-Hasselbalch equation. The consistent interpretation of the shift is that a water-soluble mixed-charge anionic dimer forms, with the stoichiometry XHX [19]. Similar species have been observed in numerous studies, and in some cases, LC/MS was able to corroborate the hypothesized aggregate formations [18]. The equilibrium constant for the reaction $\mathrm{XH}+\mathrm{X}^{-}=\mathrm{XHX}^{-}$is $\log K_{\mathrm{XHX}}=5.21 \pm 0.18 \mathrm{M}^{-1}$. 
(a) DIPRENORPHINE

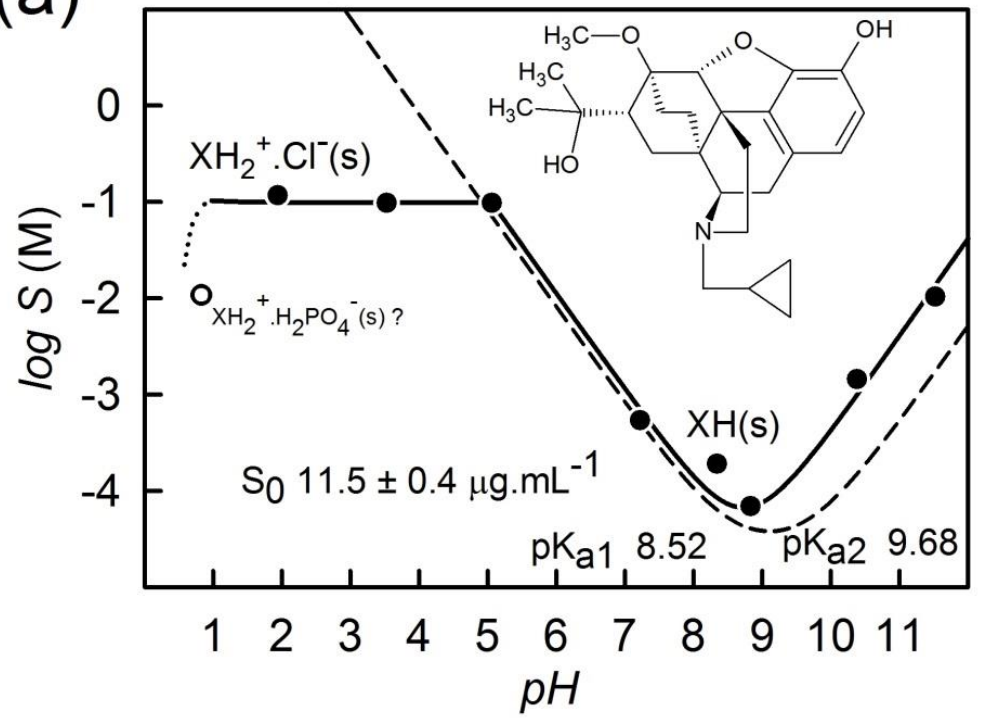

(b) CODEINE
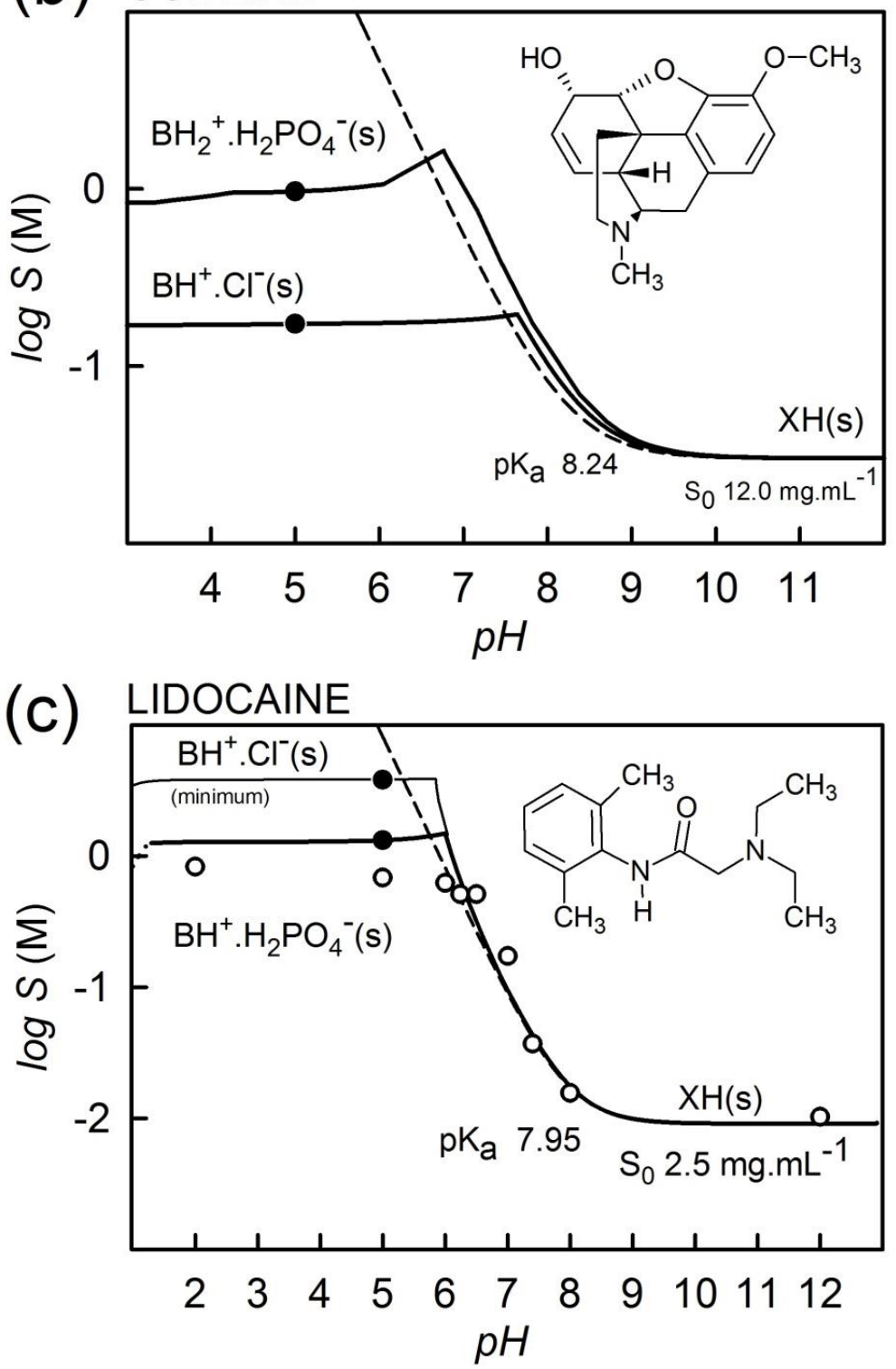

Figure 1. Solubility-pH profiles of the three model drugs studied. (See text) 


\section{Codeine Hydrochloride and Dihydrogenphosphate}

Figure $1 \mathrm{~b}$ shows the codeine hydrochloride $\left(\mathrm{BH}^{+} \mathrm{Cl}\right)$ and phosphate $\left(\mathrm{BH}^{+} \mathrm{H}_{2} \mathrm{PO}_{4}{ }^{-}\right) \log S-\mathrm{pH}$ profiles. The curve was calculated assuming the intrinsic solubility, $\mathrm{pS}_{0}=1.52\left(\mathrm{~S}_{0}=12 \mathrm{mg} \mathrm{mL}^{-1}\right.$, assuming phosphate salt molecular weight), reported by Kuhne et al. [24]. Although single pH measurements were made, the whole curve adds useful perspective to the expected solubility $-\mathrm{pH}$ relationship. The assignment of the types of salts formed is possible in the way the assays were designed. The codeine phosphate assay had no source of chloride, and thus revealed the phosphate $\mathrm{p} K_{\mathrm{sp}}=1.00\{1.11\}$. The codeine chloride assay indicated a significantly higher $\mathrm{p} K_{\mathrm{sp}}=1.59\{1.57\}$, suggesting that the salt precipitate was that of the chloride. Furthermore, the solubility product for the phosphate salt in the case of the chloride was not exceeded (Table 3), suggesting the absence of phosphate salt in the chloride assay.

\section{Lidocaine Free Base and Hydrochloride}

Figure 1c shows the lidocaine phosphate $\left(\mathrm{BH}^{+} \mathrm{H}_{2} \mathrm{PO}_{4}{ }^{-}\right) \log \mathrm{S}-\mathrm{pH}$ profile. The chloride was very soluble with $S_{\mathrm{BH}}>1 \mathrm{~g} \mathrm{~mL}^{-1}$. The chloride $\mathrm{p} K_{\mathrm{sp}}$ in Table 3 refer to the minimum possible values: $\mathrm{p} K_{\mathrm{sp}}{ }^{\mathrm{BHCl}}=-0.99\{-0.85\}$, suggesting that the chloride salt is at least 50 times more soluble than the phosphate salt. The solid curve was calculated assuming the intrinsic solubility, $\mathrm{p} S_{0}=2.04\left(S_{0}=2.5 \mathrm{mg} \mathrm{mL}^{-1}\right.$, assuming $\mathrm{BH}^{+} \mathrm{Cl}^{-}$molecular weight), reported by Bergström et al. [16]. As in the case of the codeine assays, the assignment of the types of salts formed with lidocaine is possible in the way the assays were designed. The lidocaine free base assay had no source of chloride, and thus revealed the phosphate $p K_{\mathrm{sp}}=0.85\{0.88\}$. The solubility product for the phosphate salt in the case of the chloride was not exceeded (Table 3 ), suggesting the absence of phosphate salt in the chloride assay.

The unfilled circle symbols in Figure $1 \mathrm{c}$ are the solubility values reported by Bergström et al. [16], using the miniaturized shake-flask method $\left(25^{\circ} \mathrm{C}, 0.15 \mathrm{M}\right.$ phosphate buffer, $24 \mathrm{~h}$ incubation).

Even though the $\mathrm{p} K_{\mathrm{sp}}$ values of phosphate precipitate in the free base case were nearly identical for the two buffer systems used, the morphology of the crystals isolated was quite different, as shown in Figure 2, with the Sörensen buffer producing much larger and better-formed crystals, compared to the BrittonRobinson buffer (approx. 800 vs. $60 \mu \mathrm{m}$, respectively). The X-ray powder diffractograms in Figure 3 confirmed that the crystals formed in the free base assay were those of the same phosphate salt polymorph. 

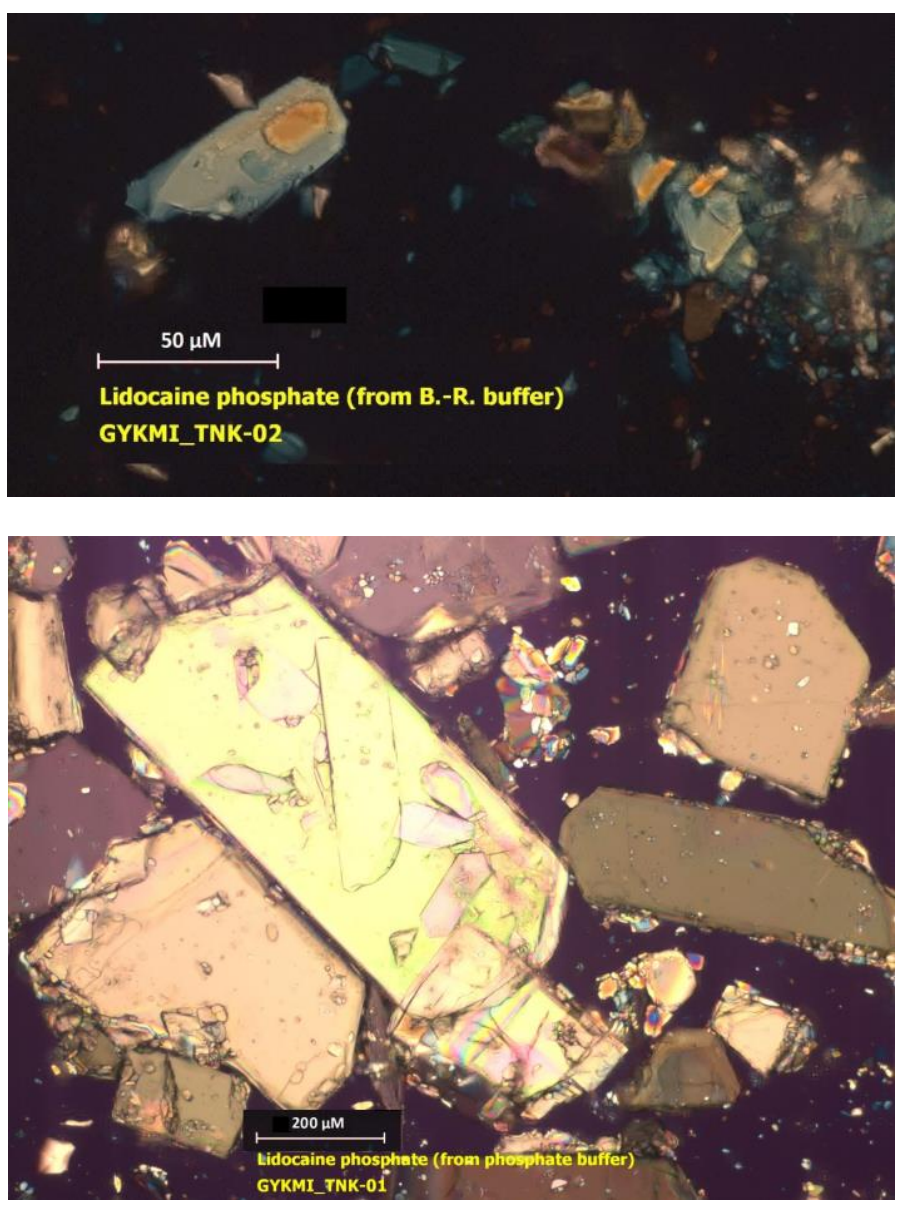

Figure 2. Microphotographs of lidocaine phosphate solids obtained from solubility experiments: (a) Britton-Robinson buffer, (b) Sörensen buffer.

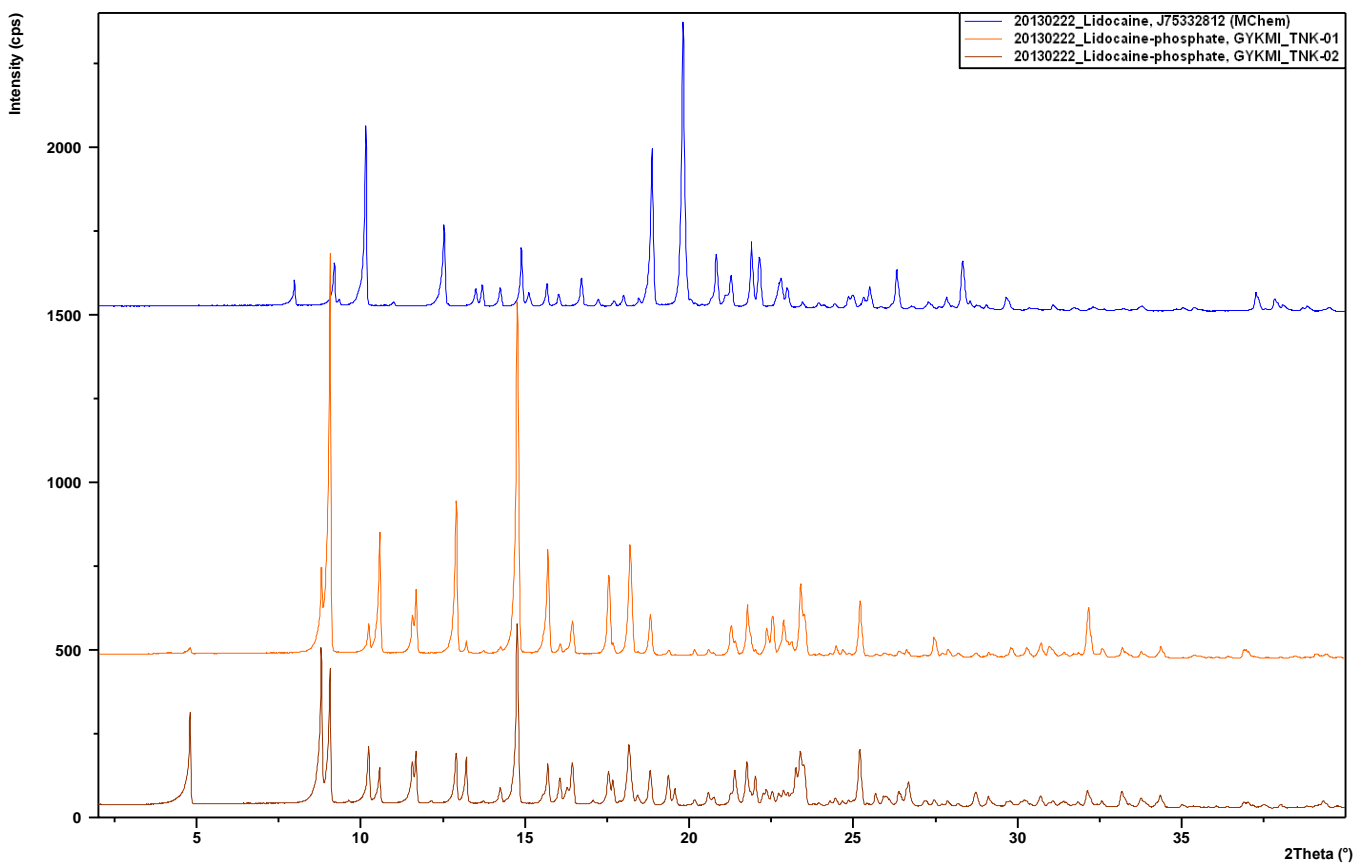

Figure 3. X-ray powder diffractograms of reference lidocaine base (blue), lidocaine phosphate from solubility measurement in Britton-Robinson buffer (brown) and in Sörensen buffer (orange). 


\section{Conclusion}

The design of salt solubility assays here and the data analysis capability of the new program, $p$ DISOL-X offered an opportunity to critically investigate issues related to the challenges of characterizing salt solubility products, such as the high ionic strengths, which can affect values of equilibrium constants and the calibration of $\mathrm{pH}$ electrodes. The "anomalies" in the shapes of $\log S-\mathrm{pH}$ profiles that cannot accurately be predicted by the Henderson-Hasselbalch may be common with sparingly-soluble or practically-insoluble drugs, such as diprenorphine, but are not always easy to recognize unless accurately-determined $\mathrm{p} K_{\mathrm{a}}$ values are available [28]. Phosphate buffers can dramatically influence the solubility profiles of ionizable drugs, as shown here and elsewhere $[16,29]$. These and other similar complications may be common, but are not always easy to interpret quantitatively. In such instances, $p$ DISOL-X may be a helpful data analysis and simulation tool. It can further aid in the analysis of dissolution mechanisms which depend on the salt solubility of drugs.

\section{Appendices}

\section{A) Explicit Solubility - $p H$ Equations}

The idealized relationship between solubility and $\mathrm{pH}$ can be readily derived for simple equilibrium models. The "model" refers to a set of equilibrium equations and the associated equilibrium constants. The following are examples of such derivations correspond to a diprotic ampholyte.

\section{Precipitation of Diprotic Amphoteric Drug, XH (Henderson-Hasselbalch Equation)}

In the case of a diprotic amphoteric drug, a saturated solution can be defined by the equations and the corresponding constants

$$
\begin{array}{llll}
\mathrm{XH}_{2}^{+} & \leftrightarrows & \mathrm{H}^{+}+\mathrm{XH} & K_{\mathrm{a} 1}=\left[\mathrm{H}^{+}\right][\mathrm{XH}] /\left[\mathrm{XH}_{2}^{+}\right] \\
\mathrm{XH} & \leftrightarrows & \mathrm{H}^{+}+\mathrm{X}^{-} & K_{\mathrm{a} 2}=\left[\mathrm{H}^{+}\right]\left[\mathrm{X}^{-}\right] /[\mathrm{XH}] \\
\mathrm{HX}(\mathrm{s}) & \leftrightarrows & \mathrm{XH} & \mathrm{S}_{0}=[\mathrm{XH}]
\end{array}
$$

Solubility, $\mathrm{S}$, at a particular $\mathrm{pH}$ is defined as the mass balance sum of the concentrations of all of the species dissolved in the aqueous phase:

$$
S=\left[\mathrm{X}^{-}\right]+[\mathrm{XH}]+\left[\mathrm{XH}_{2}^{+}\right]
$$

where the square brackets denote molar concentration of species. The above equation can be transformed into an expression containing only constants and $\left[\mathrm{H}^{+}\right]$(as the only variable), by substituting the ionization and solubility Eqs. A1-A3 into Eq. A4.

$$
\begin{aligned}
& \log S=\log \left(K_{\mathrm{a} 1} /\left([\mathrm{XH}]\left[\mathrm{H}^{+}\right]\right)[\mathrm{XH}]\left[\mathrm{H}^{+}\right] / K_{\mathrm{a} 1}+[\mathrm{XH}]+[\mathrm{XH}]\left[\mathrm{H}^{+}\right] / K_{\mathrm{a} 1}\right) \\
& =\log [\mathrm{XH}]+\log \left(K_{\mathrm{a} 2} /\left[\mathrm{H}^{+}\right]+1+\left[\mathrm{H}^{+}\right] / K_{\mathrm{a} 1}\right) \\
& =\log S_{0}+\log \left(1+10^{-\mathrm{pKa} 2+\mathrm{pH}}+10^{+\mathrm{p} K \mathrm{a} 1-\mathrm{pH}}\right)
\end{aligned}
$$

Eq. A5 is often called the Henderson-Hasselbalch $(\mathrm{HH})$ equation for a diprotic ampholyte, and describes a U-shaped $\log S-\mathrm{pH}$ curve. At the low-pH bend in the $\log S-\mathrm{pH}$ curve, the $\mathrm{pH}$ equals the $\mathrm{p} K_{\mathrm{a} 1}$; at the other bend, $\mathrm{pH}$ equals the $\mathrm{p} K_{\mathrm{a} 2}$.

\section{Salt Precipitation of Diprotic Amphoteric Drug, $\mathrm{XH}$}


Eq. A5 considers only one precipitate, that of the uncharged species $\mathrm{XH}$, defining the "intrinsic solubility" concentration, $\mathrm{S}_{0}$. If the solubility experiment were carried out as an acid-base $(\mathrm{HCl} / \mathrm{NaOH})$ titration, over a wide range $\mathrm{pH}<<\mathrm{p} K_{\mathrm{a} 1}$ to $\mathrm{pH} \gg>\mathrm{p} K_{\mathrm{a} 2}$, with enough excess compound added that the solubility products of the salts $\mathrm{XH}_{2}{ }^{+} \mathrm{Cl}^{-}(\mathrm{s})$ and $\mathrm{Na}^{+} \mathrm{X}^{-}(\mathrm{s})$ are exceeded, then the curve would have regions at low $\mathrm{pH}$ and high $\mathrm{pH}$ that would not behave as indicated by the $\mathrm{HH}$ equation. To describe these processes, two additional solubility equations need to be added to Eqs. A1-A3:

$$
\begin{array}{lll}
\mathrm{XH}_{2}^{+} \mathrm{Cl}^{-}(\mathrm{s}) \leftrightarrows & \mathrm{XH}_{2}^{+}+\mathrm{Cl}^{-} & K_{\mathrm{sp1} 1}=\left[\mathrm{XH}_{2}^{+}\right]\left[\mathrm{Cl}^{-}\right] \\
\mathrm{Na}^{+} \mathrm{X}^{-}(\mathrm{s}) \quad \leftrightarrows & \mathrm{Na}^{+}+\mathrm{X}^{-} & K_{\mathrm{sp2} 2}=\left[\mathrm{Na}^{+}\right]\left[\mathrm{X}^{-}\right]
\end{array}
$$

\section{Hydrochloride Salt of the Drug, $\mathrm{XH}_{2}{ }^{+} \mathrm{Cl}^{-}(\mathrm{s})$}

If enough compound is added to the suspension and the $\mathrm{pH}$ is gradually lowered, well below $\mathrm{p} K_{\mathrm{a} 1}$, at a critical $\mathrm{pH}$ point, called $\mathrm{p} K_{\mathrm{a} 1}{ }^{\text {Gibbs }}[30,31]$, the $\mathrm{HH}$ equation is replaced by an approximately horizontal line.

In the salt solubility region, $\mathrm{pH}<\mathrm{p} K_{\mathrm{a} 1}{ }^{\text {Gibbs }}$, Eq. A4 still holds, but $\left[\mathrm{XH}_{2}{ }^{+}\right]$becomes constant, instead of $[X H]$. Eq. $A 5$ can be modified (using Eqs. $A 1, A 2$ and $A 6$ ) to reflect this.

$$
\begin{aligned}
\log S= & \log \left(K_{\mathrm{aa} 2} K_{\mathrm{a} 1}\left[\mathrm{XH}_{2}^{+}\right] /\left[\mathrm{H}^{+}\right]^{2}+K_{\mathrm{a} 1}\left[\mathrm{XH}_{2}^{+}\right] /\left[\mathrm{H}^{+}\right]+\left[\mathrm{XH}_{2}^{+}\right]\right) \\
& =\log \left[\mathrm{XH}_{2}^{+}\right]+\log \left(1+10^{-\mathrm{pKa} 1-\mathrm{pK} \mathrm{K} 2+2 \mathrm{pH}}+10^{-\mathrm{pKa} 1+\mathrm{pH}}\right) \\
& =\log K_{\mathrm{sp} 1}-\log \left[\mathrm{Cl}^{-}\right]+\log \left(1+10^{-\mathrm{pKa} 1-\mathrm{pKa} 2+2 \mathrm{pH}}+10^{-\mathrm{pKa} 1+\mathrm{pH}}\right)
\end{aligned}
$$

For $\mathrm{pH} \ll<\mathrm{p} K_{\mathrm{a} 1}$, the right-most logarithmic term in Eq. A8 becomes vanishingly small, and cationic-drug conditional solubility is described by $S_{(+)}=\left[\mathrm{XH}_{2}^{+}\right]=K_{\text {sp } 1} /\left[\mathrm{Cl}^{-}\right]$. Eq. A8 largely describes a horizontal line. However, since the $\mathrm{HCl}$ titrant both dilutes the solution and elevates the $\mathrm{Cl}^{-}$, the horizontal line curves downward for $\mathrm{pH}<2$, noted as the chloride "common-ion" effect, according to Eq. A8.

\section{Sodium Salt of the Drug, $\mathrm{Na}^{+} \mathrm{X}^{-}(\mathrm{s})$}

In the presence of a large excess of compound in alkaline $\mathrm{pH} \gg \mathrm{p} K_{\mathrm{a} 2}$, at the second critical $\mathrm{pH}$ point, $\mathrm{p} K_{\mathrm{a} 2}{ }^{\text {Gibbs }}$, the $\mathrm{HH}$ equation is replaced by another approximately horizontal line.

In the salt solubility region, $\mathrm{pH}>\mathrm{p} K_{\mathrm{a} 2}{ }^{\text {Gibbs }}$, Eq. $\mathrm{A} 4$ still holds, but $\left[\mathrm{X}^{-}\right]$becomes constant, while $[\mathrm{XH}]$ and $\left[\mathrm{XH}_{2}{ }^{+}\right]$are variable. Eq. A5 can be further modified (using Eqs. A1, A2 and A7) as

$$
\begin{aligned}
\log S & =\log \left(\left[\mathrm{X}^{-}\right]+\left[\mathrm{X}^{-}\right]\left[\mathrm{H}^{+}\right] / K_{\mathrm{a} 2}+\left[\mathrm{X}^{-}\right]\left[\mathrm{H}^{+}\right]^{2} /\left(K_{\mathrm{a} 1} K_{\mathrm{a} 2}\right)\right) \\
& =\log \left[\mathrm{X}^{-}\right]+\log \left(1+10^{+\mathrm{pKa} 1+\mathrm{pKa} 2-2 \mathrm{pH}}+10^{-\mathrm{pKa} 2+\mathrm{pH}}\right) \\
& =\log K_{\mathrm{sp} 2}-\log \left[\mathrm{Na}^{+}\right]+\log \left(1+10^{+\mathrm{pKa} 1+\mathrm{pK} \mathrm{Ka} 2-2 \mathrm{pH}}+10^{-\mathrm{pK} 2+\mathrm{pH}}\right)
\end{aligned}
$$

For $\mathrm{pH} \gg \mathrm{p} K_{\mathrm{a} 2}$, the right-most logarithmic term in Eq. A9 becomes vanishingly small, and conditional anionic-drug solubility is described by $S_{(-)}=\left[\mathrm{X}^{-}\right]=K_{\mathrm{sp} 2} /\left[\mathrm{Na}^{+}\right]$. Since the $\mathrm{NaOH}$ titrant both dilutes the solution and raises the sodium concentration in solution, the horizontal line curves downward for $\mathrm{pH}>12$, as a result of the sodium "common-ion" effect, according to Eq. A9.

\section{The Complete Solubility Equation}

Across the whole $\mathrm{pH}$ range, given enough compound excess, the complete solubility equation consists of three segments: (a) conditional hydrochloride salt region, $\mathrm{pH}<\mathrm{p} K_{\mathrm{a} 1}{ }^{\text {Gibbs }}$ (Eq. A8), (b) drug concentrationindependent " $\mathrm{HH}$ " region, $\mathrm{p} K_{\mathrm{a} 2}{ }^{\text {Gibbs }}>\mathrm{pH}>\mathrm{p} K_{\mathrm{a} 1}{ }^{\text {Gibbs }}$ (Eq. A5), and (c) conditional sodium salt region, $\mathrm{pH}>$ $\mathrm{p} K_{\mathrm{a} 2}{ }^{\text {Gibbs }}$ (Eq. (A9)). 


\section{Gibbs $\mathrm{pK}_{\underline{a}} \underline{\text { Values }}$}

At the lower $\mathrm{pH}=\mathrm{p}_{\mathrm{a} 1}{ }^{\text {Gibbs }}$, two solids co-precipitate: $\mathrm{XH}_{2}{ }^{+} \mathrm{Cl}^{-}(\mathrm{s})$ and $\mathrm{XH}(\mathrm{s})$. At the higher $\mathrm{pH}=\mathrm{p} K_{\mathrm{a} 2}{ }^{\text {Gibbs }}$, two different solids co-precipitate: $\mathrm{Na}^{+} \mathrm{X}^{-}(\mathrm{s})$ and $\mathrm{XH}(\mathrm{s})$. More discussion of the topic may be found in the literature $[19,30,31]$.

\section{Cationic, Anionic and Neutral Self-Aggregate Formations}

In concentrated drug solutions or in solutions containing practically insoluble drugs, oligomeric species, $\mathrm{X}_{n}{ }^{\mathrm{n}-},\left(\mathrm{XH}_{2}{ }^{+}\right)_{n}{ }^{\mathrm{n}},(\mathrm{XH})_{n},\left(\mathrm{XH} \cdot \mathrm{X}^{-}\right)_{n}{ }^{n-},\left(\mathrm{XH} \mathrm{XH}_{2}{ }^{+}\right)_{n}{ }^{n+}, \ldots$, can form. These can characteristically alter the shape of the solubility - pH profile. Consequently, most of Eqs. A1-A9 would need to be modified to accommodate aggregation equilibria. The resultant solubility equations often become very complex, and not all combinations of possible species have had the corresponding equations derived. Examples of such derivations of aggregation-solubility equations may be found in the literature [19].

\section{B) Automatic lonic Strength Compensation}

Generally, the ionic strength, $l$, changes in the course of an acid-base titration due to ionizations, additions of titrant, and dilution of concentrations. This change affects acid-base equilibrium constants. In solubility experiments designed to determine salt solubility products, $K_{\mathrm{sp}}$, the ionic strength can vary substantially during a titration, and sometimes reaches values as high as $1 \mathrm{M}$, or even higher. In contrast, ionization constants, $\mathrm{p} K_{\mathrm{a}}$, are determined at a nearly constant $I=0.15 \mathrm{M}$, under conditions where low sample concentrations (e.g., $10^{-3}$ to $10^{-6} \mathrm{M}$ ) are "swamped" by the added inert salt (e.g., $0.15 \mathrm{M} \mathrm{NaCl}$ or $\mathrm{KCl}$ ). The independently-determined $\mathrm{p} K_{\mathrm{a}}$ constants are critical to the analysis of solubility data, and thus the above large differences in ionic strength need to be factored in, as described here.

It is a reasonable practice to designate $0.15 \mathrm{M}$ as the "reference" ionic strength, $I_{\text {ref, }}$ ("physiological" level) to which all equilibrium constants are scaled in the solubility assay. In the older literature, the reference state was often chosen as zero, but in current pharmaceutical applications, $0.15 \mathrm{M}$ is usually chosen, with no loss of thermodynamic rigor [19].

Since the ionic strength at any given $\mathrm{pH}$ point in a titration is likely different from $\mathrm{I}_{\text {ref }}$, all ionization constants need to be locally transformed (from reference $I_{\text {ref }}$ to local $l$ ) for the calculation of local point concentrations. The procedure below describes such an adjustment of activity coefficients.

Consider a three-reactant system, based on reactants $\mathrm{X}, \mathrm{Y}$ and $\mathrm{H}$ (proton), whose charges are $Q_{x}, Q_{y}$, and +1 . The concentration of the $j_{\mathrm{th}}$ particular species, $C_{\mathrm{j}}$, is defined in terms of these reactants

$$
C_{\mathrm{j}}=\left[\mathrm{X}^{Q \mathrm{Xx}}\right]^{\mathrm{exj}}\left[\mathrm{Y}^{Q \mathrm{yy}}\right]^{\mathrm{eyj}}\left[\mathrm{H}^{+}\right]^{\text {ehj }} B_{\mathrm{j}}
$$

associated with the general equilibrium expression

$$
e_{x j} X+e_{y j} Y+e_{h j} H \leftrightarrows X_{e x j} Y_{e y j} H_{e h j}
$$

where $B_{j}$ is the cumulative formation constant [19], and $e_{x j}, e_{y j}$, and $e_{h j}$ are the $X, Y$, and $H$ stoichiometric coefficients, respectively, of the $j^{\text {th }}$ species.

At each $\mathrm{pH}$ point in a solubility assay, $I$ is calculated precisely, according to the general formula [32]:

$$
\begin{gathered}
I=[\mathrm{NaCl}]+[\mathrm{NaOH}]+\left[\mathrm{H}^{+}\right]+1 / 2\left\{Q_{\mathrm{x}}\left(1+Q_{\mathrm{x}}\right) x+Q_{\mathrm{y}}\left(1+Q_{\mathrm{x}}\right) y+\Sigma Q_{\mathrm{j}}\left(1+Q_{\mathrm{j}}\right) C_{\mathrm{j}}\right\} \\
\left.+1 / 2\left\{\left|Q_{\mathrm{x}}+\mathrm{n}_{\mathrm{x}}\right|-Q_{\mathrm{x}}-\mathrm{n}_{\mathrm{x}}\right\} X+1 / 2\left\{\left|Q_{\mathrm{y}}+\mathrm{n}_{\mathrm{Y}}\right|-Q_{\mathrm{y}}-\mathrm{n}_{\mathrm{Y}}\right)\right\} Y
\end{gathered}
$$


The last two terms in braces in Eq. B3 take into account any $n_{x}$ or $n_{y}$ number of counter ions introduced to the solution by drug substances in salt form (per X-or $Y$-compound, respectively).

The reference set of $B\left(I_{\text {ref }}\right)$ formation constants are locally transformed to the set $B(I)$ according to the general expression:

$$
\log \beta_{j}(I)=\log \beta_{j}\left(I_{r e f}\right)+e_{x j} \log \left[\frac{f_{x}(I)}{f_{x}\left(I_{r e f}\right)}\right]+e_{y j} \log \left[\frac{f_{y}(I)}{f_{y}\left(I_{r e f}\right)}\right]+e_{h j} \log \left[\frac{f_{h}(I)}{f_{h}\left(I_{r e f}\right)}\right]-\log \left[\frac{f_{j}(I)}{f_{j}\left(I_{r e f}\right)}\right]
$$

where $B(I)$ refers to the ionic strength $I$, while $B\left(I_{\text {ref }}\right)$ refers to $I_{\text {ref. }}$. The ionic-strength-dependent activity coefficients of $\mathrm{X}, \mathrm{Y}, \mathrm{H}$, and $\mathrm{j}^{\text {th }}$ species (cf., Eq. B2) are denoted $f_{\mathrm{X}}, f_{\mathrm{y}}, f_{\mathrm{h}}$, and $f_{\mathrm{j}}$, respectively. A similar equation was introduced by Avdeef [32], based on the Davies-modified Debye-Hückel equation, which is reasonably useful up to $I=0.3 \mathrm{M}$. Since much higher ionic strengths are reached in salt solubility experiments, Eq. B4 in the current study is cast in an expanded activity coefficient equation based on the hydration theory proposed by Stokes and Robinson [32,33], further elaborated by Bates et al. [34] and Robinson and Bates [35] to include single-ion activities, then slightly modified by Bockris and Reddy [36], and recently applied to solubility data of a drug-like molecule by Wang et al. [7]:

$$
\log f_{i}(I)=-Q_{i}^{2} \frac{A \sqrt{I}}{1+B a_{\mathrm{i}} \sqrt{I}}-h_{i} \log a_{\mathrm{H}_{2} \mathrm{O}}+\log \left(\frac{C_{\mathrm{H}_{2} \mathrm{O}}+\sum_{j} C_{j}}{C_{\mathrm{H}_{2} \mathrm{O}}+\sum_{j}\left(1-h_{j}\right) \cdot C_{j}}\right)
$$

The first term on the right side of Eq. B5 is the Debye-Hückel equation accounting for the ion-ion electrostatic interactions; the second term is related to the decrease in the activity of water due to the work done in immobilizing some of the bulk water to hydrate ions; the third term is related to free energy change of the ions, as their concentrations effectively increase when the volume of bulk water decreases upon hydration of the ions. The parameters at $25^{\circ} \mathrm{C}$ (molar scale): dielectric constant of water, $\varepsilon=78.3$, $76.8,67.3$ at $I=0,0.15$, and $1 \mathrm{M}(\mathrm{NaCl})$, respectively [37]; the Debye-Hückel slope, $A=1.825 \times 10^{6}(\varepsilon T)^{-3 / 2}=$ $0.512,0.528,0.642$ at $I=0,0.15$, and $1 \mathrm{M}$, resp.; $\mathrm{B}=50.29(\varepsilon T)^{-1 / 2}=0.329,0.333,0.355$ at $I=0,0.15,1 \mathrm{M}$, resp.; $T$ is the absolute temperature (K). The two adjustable parameters are $\stackrel{\circ}{i}_{i}$, corresponding to the mean diameter of the $\mathrm{i}^{\text {th }}$ hydrated ion [38], and $h_{\mathrm{i}}$, the hydration number of the $\mathrm{i}^{\text {th }}$ ion [37]. The activity of water, $a_{\mathrm{H} 2 \mathrm{O}}=1.000,0.995,0.967$ at $I=0,0.15,1 \mathrm{M}$, respectively [36]. $C_{\mathrm{H} 2 \mathrm{O}}=55.51 \mathrm{M}$ (concentration of water in pure solvent form, $I=0$ ). The summation symbols in Eq. B5 are over all charged species (including the reactants) in the system.

\section{Acknowledgements}

We thank Sándor Hosztafi (Semmelweis University, Dept. of Pharmaceutical Chemistry) for the synthesis of diprenoprhine hydrochloride sample. We also thank Dénes Janke for the XRPD measurements.

\section{References}

[1] S. Miyazaki, H. Inouie, T. Nadai, T. Arita, M. Nakano, Chem. Pharm. Bull. 27 (1979) 1441-1447.

[2] S. Miyazaki, M. Oshiba, T. Nadai, J. Pharm. Sci. 70 (1981) 594-596.

[3] B.D. Anderson, R.A. Conradi, J. Pharm. Sci. 74 (1985) 815-820.

[4] B.D. Anderson, K.P. Flora, Preparation of water-soluble compounds through salt formation. In: C.G. Wermuth (Ed.). The Practice of Medicinal Chemistry. Academic Press, London, 1996, pp. 739-754.

[5] M.T. Ledwidge, O.I. Corrigan, Int. J. Pharm. 174 (1998) 187-200. 
[6] A.T.M. Serajuddin, M. Pudipeddi, Salt selection strategies, in: Stahl PH, Wermuth CG (Eds.), Handbook of Pharmaceutical Salts: Properties, Selection, and Use, Wiley-VCH, Weinheim, 2002, pp. 135-160.

[7] Z. Wang, L.S. Burrell, W.J. Lambert, J. Pharm. Sci. 91 (2002) 1445-1455.

[8] P.H. Stahl, Salt selection, in: R. Hilfiker (Ed.), Polymorphism in Pharmaceutical Industry, Wiley-VCH, Weinheim, 2006, pp. 309-322.

[9] T. Higuchi, M. Gupta, L.W. Busse, J. Amer. Pharm. Assoc. (Sci. Ed.) 42 (1953) 157-161.

[10] T.J. Roseman, S.H. Yalkowsky, J. Pharm. Sci. 62 (1973) 1680-1685.

[11] D.J. Attwood, J. Gibson, J. Pharm. Pharmacol. 30 (1978) 176-180.

[12] A. Fini, G. Fazio, G. Feroci, Int. J. Pharm. 126 (1995) 95-102.

[13] Z. Wang, K.R. Morris, B. Chu, J. Pharm. Sci. 84 (1995) 609-613.

[14] Y. Surakitbanharn, R. McCandless, J.F. Krzyzaniak, R.-M. Dannenfelser, S.H. Yalkowsky, J. Pharm. Sci. 84 (1995) 720-723.

[15] W.H. Streng, D.H.-S. Yu, C. Zhu, Int. J. Pharm. 135 (1996) 43-52.

[16] C.A.S. Bergström, K. Luthman, P. Artursson, Eur. J. Pharm. Sci. 22 (2004) 387-398.

[17] A. Avdeef, Adv. Drug Deliv. Rev. 59 (2007) 568-590.

[18] E. Shoghi, E. Fuguet, E. Bosch, C. Ràfols, Eur. J. Pharm. Sci. 48 (2013) 291-300.

[19] A. Avdeef, Absorption and Drug Development, Second Edition. Wiley-Interscience, Hoboken, NJ, 2012.

[20] A. Avdeef, J.J. Bucher, Anal. Chem. 50 (1978) 2137-2142.

[21] E. Baka, J. Comer, K. Takács-Novák, J. Pharm. Biomed. Anal. 46 (2008) 335-341.

[22] A. Avdeef, D.A. Barrett, P.N. Shaw, R.D. Knaggs, S.S. Davis, J. Med. Chem. 39 (1996) 4377-4381.

[23] A. Avdeef, K.J. Box, J.E.A. Comer, C. Hibbert, K.Y. Tam, Pharm. Res. 15 (1997) 208-214.

[24] R. Kuhne, R-U. Ebert, F. Kleint, G. Schmidt, G. Schuurmann, Chemosphere 30 (1995) 2061-2077.

[25] E. Shoghi, E. Fuguet, C. Ràfols, E. Bosch, Chem. Biodivers. 6 (2009) 1789-1795.

[26] C.M. Wassvik, A.G. Holmén, R. Draheim, P. Artursson. LogP-independent solubility of drugs molecular descriptors for solid-state limited solubility. In: C.M. Wassvik. PhD Thesis, Univ. Uppsala, 2006.

[27] S. Pinsuwan, P.B. Myrdal, Y.-C. Lee, S.H. Yalkowsky, Chemosphere 35 (1997) 2503-2513.

[28] G. Völgyi, E. Baka, K. Box, J. Comer, K. Takács-Novák, Anal. Chim. Acta 673 (2010) 40-46.

[29] W.H. Streng, S.K. Hsi, P.E. Helms, H.G.H. Tan, J. Pharm. Sci. 73 (1984) 1679-1684.

[30] A. Avdeef, Pharm. Pharmacol. Commun. 4 (1998) 165-178.

[31] W.H. Streng, Int. J. Pharm. 186 (1999) 137-140.

[32] A. Avdeef, J. Pharm. Sci. 82 (1993) 183-190.

[33] R.H. Stokes, R.A. Robinson, J. Amer. Chem. Soc. 70 (1948) 1870-1878.

[34] R.G. Bates, B.R. Staples, R.A. Robinson, Anal. Chem. 42 (1970) 867-871.

[35] R.A. Robinson, R.G. Bates, Marine Chem. 6 (1978) 327-333.

[36] J.O'M. Bockris, A.K.N. Reddy, Modern Electrochemistry, Vol. 1. Plenum Publishing Corp., New York, NY, 1973.

[37] R.A. Robinson, R.H. Stokes, Electrolytic Solutions. $2^{\text {nd }}$ Revised Ed. Dover Publications, Inc., Mineola, NY, 2002.

[38] J. Kielland, J. Amer. Chem. Soc. 59 (1937)1675-1678. 